\title{
Urban community gardens: emerging models for sustainable health, democracy and water policy
}

\author{
V. E. Ward \\ Department of Recreation and Tourism Management, \\ California State University, USA
}

\begin{abstract}
This paper provides a comparative analysis of community gardens as they expand the scope of purpose to address social, political and health needs of densely populated areas. Water policies in several large urban areas are investigated to assess for their impact on edible gardens/food production, water sources/use and the potential for identifying community gardens as a bridge to stabilizing access to increasing sustainable and scale-able food production that can be reinterpreted in a variety of cultures and climates. Particularly, the reintroduction of small scale, community-based agriculture is examined as a model for increasing community participation as well as managing health, wellness and water.
\end{abstract}

Keywords: community gardens, water efficiency, sustainability, social justice.

\section{Introduction}

Water is essential to overall health and wellness of human beings. The human body, in fact, is comprised of 50-70\% water depending on age and gender (Helmenstine [18]), and is critical to maintaining overall quality of life. It is estimated that 800 million people around the world, consistent access to water to meet basic needs for hydration and hygiene (Charity:water [7]). The World Health Organization has identified Millennium Development Goal 7, target 10 which "aims at halving by 2015 the proportion of people without sustainable access to safe drinking water and basic sanitation (Health through Safe Drinking Water and Sanitation, WHO [16])". Significantly, time spent locating and transporting water means less time for other things like education and economic development, while differentially impacting the well-being of woman and children. 
Although water covers approximately $75 \%$ of the earth's surface, water is considered an increasingly compromised resource, with $70 \%$ of the world's fresh water being used for agriculture; so if not well managed will result in increased scarcity (Seltzer [29]). It is important to recognize that "water usage differs highly between developing countries and developed ones. Developing countries use $90 \%$ of their water for agriculture, $5 \%$ for industry, and 5\% for urban areas. Developed countries use $45 \%$ of their water for agriculture, $45 \%$ for industry, and $10 \%$ for urban areas" (Alois [2]). Those sharing the planet must make significant strides toward sharing technological, financial and political solutions to successfully adapt to projected population growth by developing cooperative and sustainability-based models that address anticipated needs. The purpose of this paper is to examine community gardens as a case study exemplifying a potential model of sustainable practice promoting health, democracy and effective water use policies.

\section{Water rights, laws and policies in the United States: California}

There is no universal policy about water rights and ownership. For some, the notion that anyone could own the rights to water to the exclusion of others who might need it seems ludicrous. However, water and particularly access to clean water has been a source of power and control throughout history. One can think of the manipulation of the Nile recounted in Bible stories or reports of damming water or allowing gates of reservoirs to run unchecked to ruin dwellings, crops and wildlife to kill off enemies. On the other hand, inability to control water results in flooding with similar losses of living things, industry and agriculture. Natural disasters, such as hurricanes, tsunamis and typhoons occur in various regions of the world where residents lament too much water as opposed to too little. Intentional flooding, ironically may be employed to achieve either positive or negative outcomes.

The United States provides an interesting case study, and notably examining water practices in the State of California, because both the nation and the state have a long and varied history regarding water use, as well as regional geological diversity ranging from very abundant to very limited water. California water issues have gained some notoriety due to the drought conditions from 2011-2014. At the beginning of 2015 water levels continued to be insufficient to replace depleted aquifers in order to restore them to desired levels for the growing state that produces much of the food for residents throughout the region.

Legal rights to water were historically divided into two categories; ground water and surface water, with rights to use, store, divert the resource related to adjacent property ownership (riparian) or correlative rights; being above the inground resource (Getches [14]).Water law and rights in the United States are primarily adjudicated at the state or county level, with major cities and municipalities establishing their own systems, priorities, categories and regulation for water use. 
The State of California provides an interesting framework to better understand the issues addressed in this paper since it is a western state, a geographically, climatically and ethnically diverse state. California goes through cyclical droughts, but has adapted to the vagaries of these changes by adopting a wide array of policies, including residential water restrictions and an extensive water management bureaucracy. California produces fruits and vegetables for people all over the western region, and is known for its agriculture as well as for the movie industry, beaches and mountain resorts.

Ironically, it is precisely the solutions to water and food production that led to the speculation about alternatives to business-as-usual. After a three year drought, some wineries were threatened with production loss, wells went dry and concerns about the long-term sustainability of mass agricultural production and inconsistently monitored use of water has led to the consideration of decentralizing food production to a more manageable scale. The social, political and economic implications of doing so, however, are by no means insignificant or inconsequential. This begins a discussion about the potential role for community gardens as holding a more critical role in the world's future of both food and water.

\section{Community gardens}

Community gardens are an elusive entity to examine because while the definition is relatively simple, "a plot of land where neighborhoods can come together to grow food and build community (Green and Haines [15])", the manner in which community gardens evolve, particularly in urban areas, are based on both formal and informal processes that are influenced by zoning, water policy and oversight by municipal government agencies. Availability of federal and local grants may further complicate distinctions among urban farms, parks, and initiatives to make good use of vacant lots, and even public works initiatives to create edible landscapes. Urban gardening, a notable outgrowth of Earth Day in 1970, declined over several generations for a variety of reasons; ranging from fear of rodent infestation, to complaining neighbors (Not in My Back Yard-NIMBYism) and in some areas, water cost and seasonal water use restrictions. A Community Garden Policy Reference Guide (2012) was developed by the Public Health Law Center at the William Mitchell College of Law that addresses the role of local governments, land use planning and zoning, community garden group considerations and liability concerns. This paper examines several aspects of community gardens as they intersect with critical global issues such as water, food, health, justice and sustainability.

Parks and recreation departments throughout the United States have embraced numerous urban parks initiatives designed to maximize city environments, while harnessing waterfront development to increase environmental quality, make efficient use of resources while increasing access to open space and high quality leisure time experiences. Beard [6] summarizes several projects across the United States ranging from New York to Baltimore to Seattle that exemplify the wide diversity of approaches uses to engage urban dwellers with nearby surface water, while improving the connection with, and increasing pride in place. Los Angeles 
launched a 30-year plan to revitalize its "concrete" river to connect the city and increase recreational access for diverse communities throughout the city. Barriers associated with achieving these goals for citizens are often complicated by a confusing web of water policy and administrative oversight.

\section{Community gardens and water policy}

Community gardens have often been associated with food shortages during war or economic downturns. Urban gardens are not new in the United States and urban dwellers with rural roots often retained a small garden plot in their backyards. Expansion of suburbs led to restriction on the use of municipal water, meaning potable water in many cases within the United States. In some cases, using water for gardens was considered inefficient, unnecessary and primarily a recreational pastime or hobby. Densely populated inner city areas with vacant lots, blighted areas, abandoned housing or aborted commercial development projects often resulted in unsightly and unplanned, and thus unsupervised open spaces. There are many interrelated movements that have influenced the proliferation of community gardens such as sustainability, food sourcing concerns, bio-engineering (genetic altering) of foods, farm-to-table movement, food deserts, childhood hunger, preservation of endangered species, fair trade and a variety of other causes that have direct or indirect relationships to water policy and practices.

Food deserts have been described as early as 2002 "a deprived neighborhood where food was expensive and relatively unavailable", and "its common usage has continued to be primarily qualitative (McEntee and Agyeman [22]). As a result, individuals may eat whatever is most convenient, and that may not be a source of healthful food options. Smoyer-Tomic et al. [31] conducted a study in Edmonton Canada and found that both behavioral and environmental factors created a "causal pathway for obesity"). They found that in Edmonton, "predominantly low wealth, renter-occupied and lone parent neighborhoods have greater exposure to fast food outlets, which is not offset by better supermarket access". In Australia, distance from food options was examined with recommendations ranging from transportation policy changes to home delivery of groceries, "since people who live in food deserts often have no option but to rely on smaller stores where prices are higher and the quality and variety of fresh food is more limited" (Coveney and O’Dwyer [11]).

Childhood hunger and a general trend toward increased incidences of obesity have also brought attention to controlling food quality and access among US subgroups like African Americans can be correlated with where one lives (Kwate et al. [20]). The authors cited higher densities of fast food availability as directly related with obesity among the population, regardless of socio economic status and recommended policy level changes to limit fast food chains in commercial areas predominantly visited by African Americans since "fast food consumption has been found to be a strong contributor of dietary fat among African American women... and Blacks frequented fast food restaurants significantly more often than Whites". These groups also tend to have higher rates of diabetes and heart disease, 
since poor nutrition and food choices as well as lack of physical activity are identified as contributing risk factors.

In some communities, including university campuses, famers' markets are considered to provide a solution to food deserts. Larsen and Gilliand [21] examined the impact of a farmers' market coming to an area known as a food desert, and found that having a healthy food option created competition for the local market and had the overall effect of lowering prices in an environment without a supermarket. The authors conclude that "in addition to offering lower prices, the farmers' market improved access to healthy food items, for example broccoli, green grapes, and celery are now available...(and) provides residents with a significantly better variety of food items, which is arguably an important aspect of a healthy diet".

Walker et al. [36] summarize the findings of 31 studies conducted on food deserts and found that there are many areas that must be further researched to gain a complete picture of the issues and solutions - which may not be "one-size fits all". While the authors suggest further study access, policy development, a more ecological approach, what appears clear is that most solutions include close by access to affordable, high quality and a variety of healthy foods. For many residents even public transportation may be too expensive or inconvenient when it comes to shopping for food. While farmers' markets offer a partial solution, they are often not available every day, and time from harvest to table is often a key factor in maintaining the highest nutritional value. It only makes sense that another solution may be to increase food production at a more local level. Empirical studies on quality of food and quality of life are expanding all over the globe, with Canada, Australia, the UK and other so-called "western" nations acknowledging food inequities and working toward models that may work for many. Both rural and urban dwellers are impacted, just as they are by the availability of water to raise their food. But clearly, regardless of nation or location, recommended solutions must be culturally appropriate and sustainable.

\section{Sustainability}

Sustainability has emerged over time as flexible umbrella under which many of the important issues identified in previous sections of this paper may be interconnected and addressed. While far from either conceptually perfect or operationally well-defined, the use of sustainability as a framework for examining the intersections among human, ecological and built environments has triggered conferences all around the world. Results of the meetings not only include identifying common issues and obstacles to achieving desired water-related outcomes, but also the generation of lists of indicators associated with water resources management. The California Water Sustainability Framework [30] included the following list of recommended indicators from the Sustainable Water Resources Roundtable (2009); water availability, water quality, human uses and health, environmental health and infrastructure and institutions.

Different aspects of the water/food relationship have also been examined ranging from measurement issues, to data aggregation, to sub-industries such as 
fisheries and others (FAO Corporate Document Repository), but the more compelling evidence comes from citizens who have undertaken community gardens for any number of reasons. One example is the Stanford Avalon Community Garden in Los Angeles, which faced a $\$ 6000$ monthly water bill for their shared garden, and to not only decided to raise fees for plot "rental", but to institute more sustainable practices, such as drip irrigation (The Cost of Growing Fresh Food? [33]). Residents who had been flooding their plots responded by reducing water by no longer flooding their plots, but by conserving water so the social as well as health benefits will continue to accrue to the residents. In Minnesota, for example a complete "tool kit" is provided online entitled, Twin Cities Community Garden Start-up Guide (Gardening Matters [13]). Included are guidelines for setting up a gardening group, establishing a dues structure to pay for plot rental fees and watering, along with sample letters to give business people to solicit financial support or in-kind donations. Clearly, this process develops many transferable skills needed in other aspects of life and community engagement, regardless of age, gender, ethnicity or socioeconomic status.

In many ways the recent global economic downturns have further fuelled beliefs that individuals need to act and be empowered to protect themselves from failed social serving institutions. A proactive response to failed systems is to empower communities to take control at local level. Adaptations to arid climates can be seen in many areas of the world, but in the wine industry Australia and Santorini, Greece stand out as exemplars of economic shifts in products that reflect climatic change, unreliable water supplies. California wineries appear to be less certain of their ability to adjust, and have in some instances denounced European dry-farming techniques as incompatible with rainfall patterns throughout the western United States. Of interest, is the increased interest in visiting sires known for incorporating eco-friendly, water-saving practices; particularly wine tours and selecting bed and breakfast, resort/spa accommodations that showcase sustainable practices as part of the business model.

\section{Urban agriculture}

The United States Department of Agriculture (USDA) has many grants and projects to support urban agriculture, going back to the $4 \mathrm{H}$ clubs. Each state has its own Extension agency, often located at a university. Safe Food Facts for Community Gardens, for example was issued by Colorado State University Extension and recommends the use of potable (tap water) for in community gardens and rinsing produce, and recommend the use of soaker hoses or drip irrigation systems Fact Sheet No. 9.381. Emphasis on social, as well as health outcomes associated with community gardens have increased as recreational water use has become more widely recognized as part of healthy, outdoor active lifestyles that support holistic wellbeing. California water usage from 1998-2005 were sorted into commercial/industrial/institutional (20\%), Large Landscapes (10\%), Residential Landscape (34\%), Indoor Residential (31\%) and Other (5\%) (Resource Management Strategies, $\mathrm{CH} 3$ ). It is difficult from current metrics to determine whether those using shared spaces and water are a more water-efficient 
option that backyard gardening, but on the surface that seems possible. In the United States many municipal parks, recreation and community amenities departments also manage garden spaces, working alongside public works and utilities. Student researchers Casino and Wymore [27] found that "urban agriculture is 3 to 5 times more productive per acre than traditional large-scale gardening, citing Benefits of Community Gardening (2010). It would seem logical that inter-agency cooperation, and collaboration on policy development could result in a model for shared success and sustainable operations. City planners, architects, engineers, utilities experts, parks and recreation professionals, and water specialists bring their skills together with community organizers to improve health and wellbeing of citizens through well designed community gardens operating under sustainable practices. The following case study offers an example of how to introduce this topic, establish the scope and get a project started.

\section{Community gardens: a field-based case study}

Students are often challenged to understand ways to address social justice and equity in peaceful but proactive manner. Occupy movements have provided one approach, but additional models are needed. Community development employing an assets based framework is not new, but one that readily embraces the environmental, economic and social outcomes associated with community gardens as a movement that empowers local residents at a sustainable level and scale.

Preparation for the assignment included an overview of asset-based as opposed to deficit-based approaches to developing communities and making all community members (including youth, older adults and those perceived to have limited resources) aware of their ability to make positive contributions to their communities. Next, students learned about the concept of place-making, and the importance of spaces as opportunities for equitable access to healthful recreational activity participation, including gardening, even in crowded urban areas. The course instructor then shared YouTube videos and City Project website postings URL links on the course learning management system site, highlighting the impact of inequitable access to open space and outdoor recreation opportunities as directly correlated with health disparities based on zipcode (postal code). She also participated in tours of community gardens San Francisco Urban Garden Walk and "Community Gardens: Planting Seeds of Lifelong Health and Wellness" [9], and shared photos and handouts. Students were then assigned the investigation of a community garden somewhere in the contiguous United States, and one international city (London was chosen, even though Santorin, Greece was assigned). The final component of the assignment was for students enrolled in the course to select three of the class projects to present before a community-based group of young adults completing alternative high school through a local nonprofit organization. Following the presentation, both groups of students constructed and planted a small community garden next to the parking lot behind the school. Reflective comments written on post-its by university course participants are summarized in Appendix A. 


\section{Comparative analysis of community garden policies and practices}

Following the conclusion of the semester analyses of findings on the practices and policies employed by United States community gardens was completed, and a summary is presented below. Phoenix Arizona was added to round out the analysis by including a city in the arid, desert southwest region of the US, making the sample more inclusive of all regions.

Table 1 summarizes basic information available about community gardens located in several major cities in different regions of the United States. It also provides the water efficiency rating for each state. As noted, there is no uniform system in place throughout the country when it comes to policies on community gardens. It is believed that some type of community garden has existed in the country since the 1800 s, and many have been a combination of flowers and vegetables. Today, space-saving varieties of fruit and nut trees are also encouraged, but must be compact so as not to over-shade crops requiring lots of sunlight. Due to concerns about the health of bees and other pollinators, some locations support bee hives or other pollinators nearby.

Upon examination, it becomes quite clear from the figure that the states with lots of water were not rated high for their water efficiency plans and practices, but those states that are less certain about the resource must devise plans and systems to retain access to and fair use of it. If water is a shared and finite resource, it would seem important for the generation of fair and consistent (but not necessarily uniform) policies for all states. Several gardens have non-profit partners or directly reach out to schools, youth-serving organizations, older adult centers and other disadvantaged groups.

Purposes of community gardens also vary. While some are specifically to encourage growing food to enhance family diets, others are used to diversify food given away to the homeless or needy, at shelters or food pantries. Other gardens are used to beautify vacant lots or even the spaces between sidewalks and curbs that are often planted with "street trees" known as Hellstrips (Hadden [16]). While some community gardens are quite small, others approach the size of a true urban farm (Rich [28]). Policies and practices must be tailored to meet both current and future community goals, objectives natural constraints. Arnold [4], in a similar manner, links environmental justice to fair and healthy land use, and connects community participation in the planning process to achieving justice-related outcomes. As a concrete example, the author points to the long term goal of revitalizing the Los Angeles River and that project's potential to achieve many goals for the city and its current and future residents. It is about more than attracting business to the area and increasing recreational opportunities for all citizens. In essence the LA River project is viewed as changing the heart and soul of the city. 


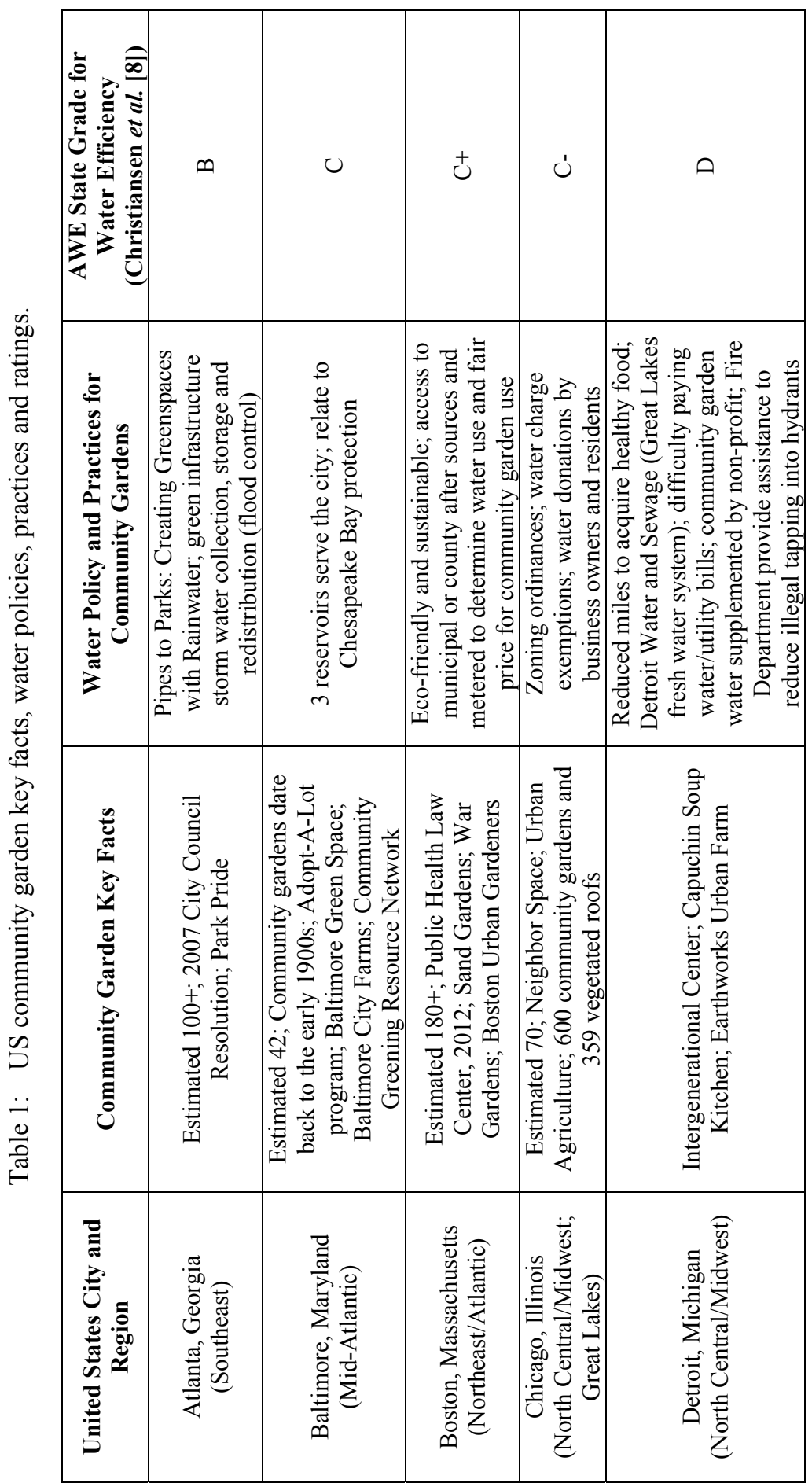




\begin{tabular}{|c|c|c|c|c|c|c|}
\hline 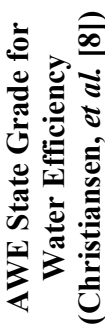 & $\dot{\psi}^{\prime}$ & U' & $\dot{\psi}^{\prime}$ & $\cup$ & $\stackrel{+}{m}$ & $\dot{\psi}^{\prime}$ \\
\hline 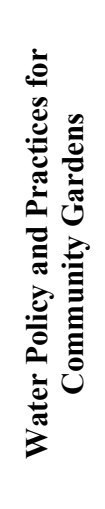 & 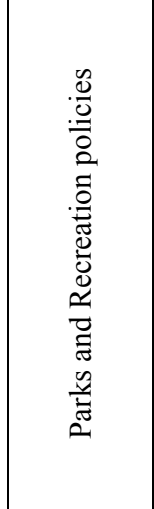 & 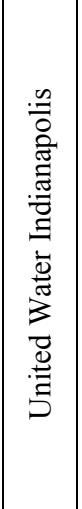 & 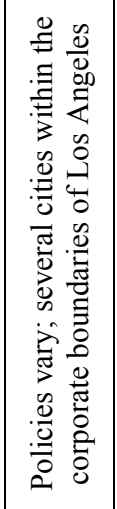 & 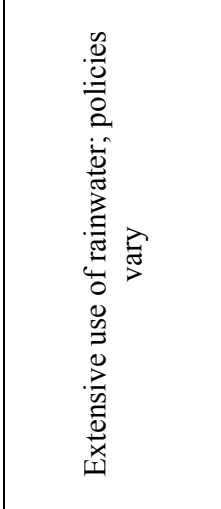 & 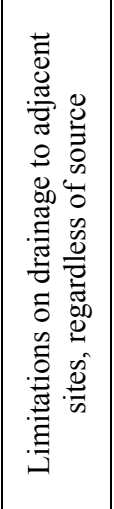 & 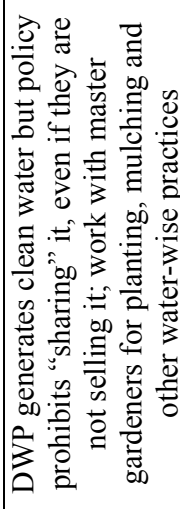 \\
\hline 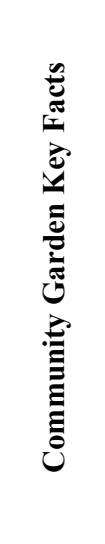 & 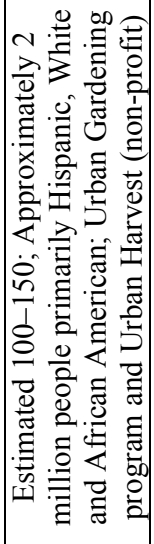 & 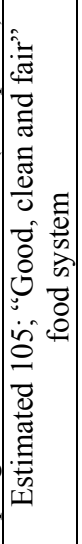 & 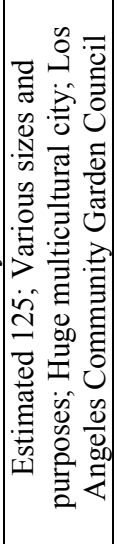 & 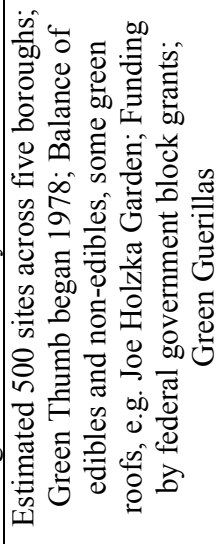 & 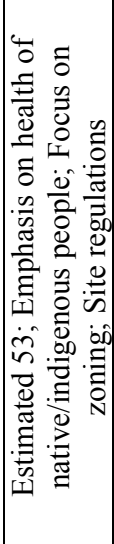 & 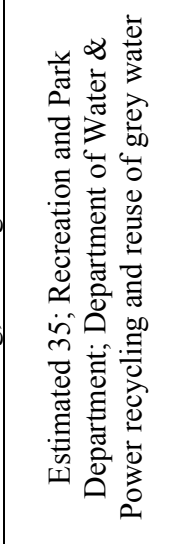 \\
\hline 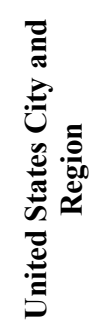 & 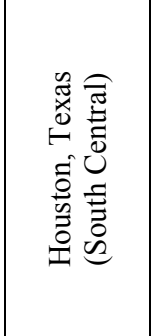 & 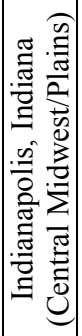 & 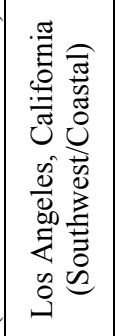 & 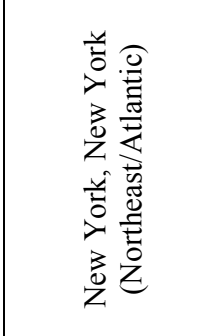 & 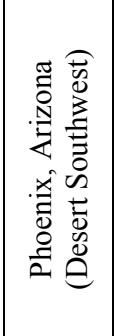 & 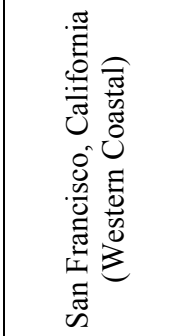 \\
\hline
\end{tabular}




\section{Conclusions and recommendations}

The concept of community gardens is not a new one, but can be seen as an adaptation to climatic, social and political changes that have prompted consideration of new ways to solve problems at a local level. Whether, drought, war, global warming, natural disaster or political unrest, water remains a finite resource that is shared regardless of national borders or geo-political policy. Of particular interest in this paper has been a focus on holistic health and well-being that is impacted by access to clean water, nutritious food and building a sense of community. Specifically, the ever-expanding concerns with food sourcing and sustainable living have brought attention to scalable farming that shifts control to local areas and promotes social equity; thus abating child hunger, abandoned urban lots and wasteful water practices. Charity:water emphasizes the disproportionately negative impact that lack of clean water has on women and children. It is important to get both populations involved through formal school curriculum, voluntary organizations or informal women's groups.

Changing climatic and political realities require adaptation on many levels ranging from individual to institutional to international. Large scale manufacturing and food production were once deemed to be the more efficient approaches to providing affordable products, access to a variety of foods and ensuring clean water supply. In the middle of the second decade of the new millennium, both developing and developed countries express increased dissatisfaction with basic components of quality of life associated with the components identified above. The inability of existing systems to meet expectations of citizens has called into question most centralized approaches to delivering consistent services to all citizens. California's 20X2020 Water Conservation Plan [7] is an exciting model because it identifies both strengths and weaknesses of existing plans, including the potential uses for non-potable water. Table 12, entitled Implementation Barriers and Recommendations, for example, identified 6 key areas that need to be addressed including (1) the overall governance plan, (2) the voluntary nature of existing conservation, (3) data reporting and analysis, (4) funding, (5) appliance efficiency and codes, and (6) water pricing. The plan is only five years old but can already benefit from a face-lift in light of changing technologies, the drought cycle and 2014 legislation.

Notably, the expectations of those living in wealthier nations have become more moderate and realistic; assurance of basic health and wellness, a lessstressful, but meaningful life, and reasonable expectation of safety have supplanted dreams of wealth and power for younger generations. More and more individuals are emigrating to countries where the pace of life is slower, while aspiring to increase their overall quality of life. This means that eating less, having less, using less hydro-electric power and fossil fuels has become a twenty-first reality as opposed to a nebulous pipedream from the 1970s. The technology needed to design and monitor the operations and efficacy of community gardens is being developed to meet a shared awareness of a vital but limited resource (McEntee and Agyeman [22]; Permaculture solutions for an urban community garden [25]; Pilot Community Gardens Irrigation Meter Grant Program [26]). The 
United States has participated in international meetings to exchange ideas about water policy, including revealing some of its own missteps, particularly in its western region (Water in the US American West: 150 Years of Adaptive Strategies [37]).

But it is equally important to consider countries where water has always been considered free, available to all for whatever purpose, and whose citizens have to focus on day-to-day survival as opposed to long term strategies, due to myriad factors such as culture, poverty, war, political ideals and systemic forces beyond their control. However, literature increasing suggests that the concept is expanding to places like India (The Water Act of 1974), Singapore (Tan and Neo [32]), Taipei (Bauwens [5]); demonstrating varying levels of success. The opportunities to integrate and address many challenges, whether local or global, however, may be tackled one garden at a time. Firth et al. [12] reiterate that community develops through community gardens. As access to online information continues to slowly spread throughout the world, ability to rapidly design and establish efficient community gardens will grow as well. Infusion of water and food centered curricular and co-curricular experiences is one method of disseminating best practices and connecting citizens across socio-economic, cultural and geographic boundaries. Appendix A provides a practical example of the assessment of student learning in a sample course project.

Increased urbanization around the world has placed water at the center of many discussions related to economic stability and increased security for residents and tourists alike. Responsible travellers do not wish to be viewed as literally taking the food out of the mouths of locals - whether they can pay for it or not. Even as community gardens are increasingly considered beneficial to individuals, they are also more recognized for their potential to nurture intergenerational and crosscultural camaraderie, to serve as a deterrent to crime, as a setting in which older adults may play an important educational role, while enjoying the out-of-doors; and to increase sense of place and neighborhood, as well as encouraging more active lifestyles. But most importantly, community gardens are often the first steps in democratizing wealth (Alperovitz [3]) or blending social justice with environmental justice (McIlvaine-Newsad and Porter [23]; Nolasco [24]; Woodin and Lucas [38]). Even in water-challenged California, community gardens are described as "exceptional in its ability to address an array of public health and liveability issues across the lifespan (Twiss et al. [34]). Community gardens represent a positive alternative to government controlled, centralized food distribution programs, and may be adapted to almost any political or natural climate. When linked to other strategies for transformative change, whether at the local, city, regional or global levels, community gardens can both inspire and empower those who seek to gain more control over those two most fundamental aspects of sustainable wellbeing - water and food.

\section{Appendix A: Undergraduate case study}

University Student Post-Learning Experience Feedback on Community Gardens Assignment. 
Students enrolled in the Recreation and Community Development class were asked to provide a brief reflective "takeaway" summarizing what they learned from the community gardens assignment. Each student was given a 4 x 6 inch Post-it and asked to place it on the classroom wall when completed (without names). This allowed all students to see each other's comments, and learn from one another. A list of student comments is provided below (spelling corrected, but not grammar or punctuation).

Student Comments:

$>$ "Organic gardens are ideal for communities because it brings safety and health to the community"

$>$ "Community gardens empower communities and strengthen community ties"

$>$ "Providing opportunities 2 build relationships w/community members"

$>$ "The community garden brings people together; Los Angeles-Crenshaw community garden brought students and community members together"

$>$ "Wasn't aware of how many community gardens were inside city limits", "The psychological benefits of community gardens - community gardens increase social interaction"

$>$ "Community gardens serve many purposes and can ultimately help a lot of people no matter their social status/income"

$>$ "Community gardens are a great way to bring healthier food options to areas where fruits and vegetables may be scarce"

$>$ Fresh produce and organic eating, the importance of eating organic, the importance of teaching youth to care for something and have patience

> Community gardens in London that have plots to rent have a waiting list, it's hard to get one. This is probably an issue with a lot of community gardens

$>$ Community gardens benefit the community by providing a place of community. They also help communities in need, for example, they provide a healthy food source

$>$ Community gardens for the fully homeless in San Francisco to get a chance for those ppl (people) to have their own vegetables and fruits. One stop shop that provides free supplies, tools, seeds and workshop for people who wants to do gardening in San Francisco

My biggest takeaway from the community gardens presentation was the diverse ways water is reused. For example, in Atlanta where they build a fountain that flowed with storm water and a system that allowed them to utilize rainwater

$>$ Atlanta used their community gardens to build a "mini city" or park area for the community

$>$ Fire departments working with the gardens and helping water the community gardens (Detroit). I thought it was a special way for the community to come together and work sustainably with one another

> Community gardens brings a neighborhood/community together. Social interactions, physical activities and health. They take an important part in each day. 


\section{Assessment of student learning}

The forgoing comments reflect key concepts from the course that relate to developing a sense of place within the urban context, connecting community gardens to health and wellness across socio-economic status, expanding opportunities for youth to learn new skills and work across generational and organizational lines, and to recognize the importance of managing water as essential to food production and human existence.

Following the research and oral report components of the assignment, students worked with a local non-profit organization to construct a raised bed and plant a small community garden at a local alternative high school. Photos were taken to document the experience. University students selected three of their course mates' presentations to be shared onsite with the community-based students, demonstrating the various academic areas of study that could be integrated into one project ranging from science, health, biology, nutrition, agriculture, urban studies, recreation and geology/hydrology. Water access was an essential element since all students recognized that without water the plants would quickly die. Since the project was in southern California, winter crop seedlings were selected from local garden centers. Few of the students in the university course were familiar with community gardens prior to the class assignment, and even fewer knew what supplies would be needed or where to find necessary equipment. Almost all of the university students learned which crops were appropriate for planting in the area during fall and winter, and all realized that water is not always available for community gardens in every community.

\section{References}

[1] Allman, W. F. \& Wagner, B. (June 8, 1992). Climate and the rise if man. U.S. News and World Report, 112, 22, pp. 60-67.

[2] Alois, P. (April, 2007). Global Crisis Overview. The Arlington Institute. http://www.arlingtoninstitute.org/wbp/global-water-crisis/441, retrieved December 4, 2014.

[3] Alperovitz. G. (2011). Democratizing wealth: Notes toward an evolutionary reconstruction of the American system. \#OCCUPYTHEFUTURE http://www.garalperovitz.com/wp-content/uploads/2011/11/occupythe future-final-printable.pdf.

[4] Arnold, C. A. (2007). Fair and Healthy Land Use: Environmental Justice and Planning. Chicago, IL: American Planning Association Report Number $549 / 550$.

[5] Bauwens, M. (December 4, 2010).The community gardens of Taipei: Taipei organic acupuncture. Marco Casagrande: Ruin Academy. http://blog.p2 pfoundation.net/the-community-gardens-of-taipei/2010/12/04.

[6] Beard, E. (2011). Nurturing nature: Three waterfront parks provide environmental stimulus. Parks and Recreation, 46, 8, pp. 48-54. 
[7] California's 20 X 2020 Water Conservation Plan (February 2010). Charity:water. Clean water means health, income and education-especially for women and kids. https://www.charitywater.org/, retrieved December 4, 2014.

[8] Christiansen, W., Dickinson, M. A., Schempp, A., Herzog, M., Mirvis, K. \& Loftus, A. (September 2012). The Water Efficiency and Conservation Scorecard: An Assessment of Laws and Policies. Funded by the Alliance for Water Efficiency (Chicago, IL.) and The Environmental Law Institute (Washington, DC).

[9] "Community Gardens: Planting Seeds of Lifelong Health and Wellness". (October 16, 2014). National Recreation and Park Association Annual Congress, Charlotte, NC, Off-Site Institute \# 9.

[10] Community Garden Policy Guidelines. Zoning Information Guide: City of Phoenix. https://www.phoenix.gov/pddsite/Documents/pdd_pz_pdf_00348 .pdf, retrieved February 16, 2015.

[11] Community Garden Policy Reference Guide. (2012). Saint Paul, MN: Public Health Law Center. Coveney, J. \& O’Dwyer, L. A. (2009). Effects of mobility and location on food access. Health \& Place, 15, pp. 45-55.

[12] Firth, C., Maye, D. \& Pearson, D. (2011). Developing community in community gardens. Local Environment, 16, 6, pp. 555-568.

[13] Gardening Matters. (September, 2009). Twin Cities Community Garden Start-up Guide. www.gardeninmaters.org, retrieved February 16, 2015.

[14] Getches, D. H. (2009). Water Law. St. Paul, Minnesota: Thomson/West.

[15] Green, G. P. and Haines, A. (2012). Asset Building \& Community Development (Third Edition). Thousand Oaks, CA: Sage Publications, Inc., p. 275.

[16] Hadden, E. J. (2014). Hellstrip Gardening. Portland, OR: Timber Press.Health through safe drinking water and basic sanitation. World Health Organization. http://www.who.int/water_sanitation_health/mdg1/en/ print.html, retrieved December 4, 2014.

[18] Helmenstine, A. M. (October 18, 2014). How much of your body is water? http://chemistry.about.com/od/waterchemistry/f/How-Much-Of-YourBody-Is-Water.htm, retrieved December 14, 2014.

[19] India: The Water (Prevention and Control of Pollution) Act 1974. http://www.elaw.org/node/1917, retrieved January 1, 2015.

[20] Kwate, N. O. A., Yau, Chun-Yip, Loh, J. \& Williams, D. (2009). Inequality in obesigenic environments: Fast food density in New York City. Health \& Place, 15, pp. 364-375.

[21] Larsen, K. \& Gilliand, J. (2009). A farmers' market in a food desert: Evaluating impacts on the price and availability of food. Health \& Place, 15, pp.1158-1170.

[22] McEntee, J. \& Agyeman, J. (2010). Towards the development of a GIS method for identifying rural food deserts: Geographic access in Vermont, USA. Applied Geography, 30, pp. 165-176.

[23] McIlvaine-Newsad, H. \& Porter, R. (2013). How does your garden grow? Environmental justice aspects of community gardens. Journal of Ecological 
Anthropology, Vol. 16, 1, pp. 69-73. http://scholarcommons.usf.edu/cgi/ viewcontent.cgi? article $=1138 \&$ context $=$ jea

[24] Nolasco, J. (2013). Sustainable Water Management for Urban Agriculture: Planting Justice, Oakland Pacific Institute. http://www.pacinst.org/ wpcontent/uploads/2013/02/sustainable_water_management_for_urban_ agriculture3.pdf.

[25] Permaculture solutions for an urban community garden. http://archives.ashs.org/abstracts/2013/abstracts13/abstract_id_15684.html

[26] Pilot Community Gardens Irrigation Meter Grant Program. San Francisco Department of Water, Power and Sewer http://sfwater.org/modules/ showdocument.aspx?documentid $=1620$.

[27] Recreation and Community Development (RTM 300) Student Papers (California State University), Northridge, Fall 2014: Casino, A. \& Wymore, K. Houston, TX; Dracopoulos, A. \& Meade, J. New York, New York; Gonzales, C. \& Mendez, A. Baltimore. Maryland; Hairapetian, R. \& Lawson, A. London. England; Hawken, T. \& Gomez, S. Detroit, Michigan; Hidalgo, A. \& Matkovich, C. Boston, Massachusetts; Huynh, U., Puerto, M. \& Newland, P. San Francisco, California; Mattern, S. Chicago, Illinois; Price, D. Indianapolis, Indiana; Reyes, J. \& Robles, G. Atlanta Georgia; Tovar, B. \& McGowan, K. Los Angeles.

[28] Rich, S. C. (2012). Urban Farms. New York, NY: Abrams.

[29] Seltzer, J. (March 19, 2013). Worldwide water supply is finite resource that must be managed. St. Louis Beacon.

[30] Shilling, F., Kahn, A., Juricich, R, Fong, V. \& Hodge, D. The California Water Sustainability Framework. (February 5, 2012), p. 14.

[31] Smoyer-Tomic, K. E., Spence, J. C., Kim, D.R., Amrhein, C., Cameron, N., Yasenovskiy, V. Cutumisu, Nicoleta, Hemphill, E., \& Healy, J. (2008). The association between neighborhood socio-economic status and exposure to supermarkets and fast food outlets. Health \& Place, 14, pp. 740-754.

[32] Tan, Leon H. H. \& Neo, Harvey. (2009). "Community in Bloom": local participation of community gardens in urban Singapore, Local Environment, 14, 6, pp. 529-539.

[33] The cost of growing fresh food? Check the water bill. (March 30, 2011). http://atimesblogs.latimes.com/home_blog/2011/03/stanford-avalocommunity-garden-1, retrieved 11/2/2014.

[34] Twiss, J., Dickinson, J., Duma. S., Kleinman, T., Paulsen, H., \& Rilveria, L. (2003). Community gardens: lessons learned from California Healthy Cities and Communities. American Journal of Public Health, 93, 9, pp. 1435-1438.

[35] Urban Agriculture and Community Gardens. San Francisco Department of Water, Power \& Sewer http://sfwater.org/modules/ showdocument.aspx?documentid=1620.

[36] Walker, R. E., Keane, C. R. \& Burke, J. G. (2010). Disparities and access to healthy food in the United States: A review of food deserts literature. Health \& Place, 16, pp. 876-884. 
[37] Water in the US American West: 150 Years of Adaptive Strategies. (March 2012). Policy Report for the $6^{\text {th }}$ World Water Forum. US Army Corps of Engineers and Consensus Building Institute.

[38] Woodin, M. \& Lucas, C. (2004). Green Alternatives to Globalisation: A Manifesto. London: Pluto Press. DOI10.1080/13549830902904060 http://dx.doi.org/10.1080/13549830902904060. 